\title{
SOWING TIMES IN ADAPTATION, STABILITY, PRODUCTIVITY, AND OIL AND PROTEIN CONTENTS OF SOYBEAN GENOTYPES ${ }^{1}$
}

\author{
EVERTON LUIS FINOTO², MARIA BEATRIZ BERNARDES SOARES ${ }^{2}$, ALESSANDRA NEVES CORREIA ${ }^{2}$, JOSÉ \\ DE ANCHIETA ALVES DE ALBUQUERQUE ${ }^{3}$, EDGLEY SOARES DA SILVA ${ }^{3 *}$
}

\begin{abstract}
No isolated factor influences soybean development and production more than the sowing date, but the responses of cultivars sown on different sowing dates depends on their sensitivity to environmental conditions. Thus, this study evaluated the adaptability and stability of 17 soybean genotypes in relation to yield, as well as to the grain oil and protein contents as a function of different sowing times. The experiment was designed in randomized blocks with three replications and a $17 \times 5$ factorial scheme. The genotypes were: Conquista, CD 223 AP, Elite, Garantia, Bioagro lineage, M-Soy 8400, M-soy 8001, Nambu, Sambaíba, Esplendor, UFVS 2006, UFVS 2005, UFVTN 102, UVF 18, UFV 16, Valiosa, Vencedora, and the five sowing dates were: $\mathrm{SD} 1=11 / 3, \mathrm{SD} 2=11 / 20, \mathrm{SD} 3=12 / 07, \mathrm{SD} 4=12 / 23$, and SD5 $=01 / 09$. The M-Soy 8001 , UFV 18 and Garantia genotypes showed high oil contents, with adaptation to all sowing dates and stability when sown on the most favorable dates. The Bioagro lineage, CD 223 AP, and Garantia genotypes were adapted and stable when sown on all sowing dates and had higher protein contents than the other genotypes, regardless of the sowing date. The Elite, Nambu, and Garantia genotypes were adapted and stable when sown on the most favorable sowing dates and presented high grain yields when sown in early December. The findings indicate that the Garantia genotype is the most suitable for the growing conditions of the central-north region of the state of São Paulo.
\end{abstract}

Keywords: Glycine max. Adaptability. Genotype-environment interaction.

\section{ÉPOCAS DE SEMEADURA NA ADAPTAÇÃO E ESTABILIDADE QUANTO A PRODUTIVIDADE E TEORES DE ÓLEO E PROTEÍNA DE GENÓTIPOS DE SOJA}

\begin{abstract}
RESUMO - Nenhum outro aspecto isolado influencia tanto o desenvolvimento e produção da soja quanto a época de semeadura, porém a resposta de diferentes cultivares em datas de semeadura distintas depende de sua sensibilidade às condições ambientais às quais estão expostas. Assim, objetivou-se no presente estudo avaliar a adaptabilidade e a estabilidade de dezessete genótipos de soja na produtividade, bem como nos teores de óleo e proteína nos grãos em função de diferentes épocas de semeadura. Utilizou-se o delineamento em blocos casualizados com três repetições, em esquema fatorial com 17 genótipos (Conquista, CD 223 AP, Elite, Garantia, linhagem "Bioagro", M-Soy 8400, M-soy 8001, Nambu, Sambaíba, Esplendor, UFVS 2006, UFVS 2005, UFVTN 102, UVF 18, UFV 16, Valiosa e Vencedora) e cinco datas de semeadura (SD1 = 11/3, SD2 = $11 / 20$, SD3 = 12/07, SD4 = 23/12 e SD5 = 09/01). Os genótipos M-Soy 8001, UFV 18 e Garantia apresentam elevados teores de óleo, com adaptação a todas as datas semeadura e estabilidade nas datas mais favoráveis. Os genótipos da linhagem "Bioagro" e os genótipos CD 223 AP e "Garantia" são adaptados e estáveis em todas as datas de semeadura e possuem maiores teores de proteína, independente das datas de semeadura. Os genótipos Elite, Nambu e Garantia estão adaptados e estáveis em nas datas mais favoráveis de semeadura e apresentam alto rendimento de grãos, nas semeaduras realizadas no início de dezembro. O Genótipo Garantia é o mais adequado às condições de cultivo da região centro-norte do estado de São Paulo.
\end{abstract}

Palavras-chave: Glycine max. Adaptabilidade. Interação genótipo x ambiente.

\footnotetext{
*Corresponding author

${ }^{1}$ Received for publication in $05 / 12 / 2020$; accepted in $07 / 22 / 2021$.

Paper extracted from the doctoral thesis of the first author.

${ }^{2}$ North Center Pole, Agência Paulista de Tecnologia dos Agronegócios, Pindorama, SP, Brazil; everton.finoto@sp.gov.br - ORCID: 00000003-1468-1428, maria.soares@sp.gov.br - ORCID: 0000-0002-0772-5325, alessandra_nc21@hotmail.com - ORCID: 0000-0002-2398$903 \mathrm{X}$.

${ }^{3}$ Center for Agricultural Sciences, Universidade Federal de Roraima, Boa Vista, RR, Brazil; anchietaufrr@gmail.com - ORCID: 0000-0003 -4391-258X, edgley_agro2008@hotmail.com - ORCID: 0000-0003-4628-1920.
} 


\section{INTRODUCTION}

Currently, the soybean crop Glycine max (L.) Merr. (Leguminosae Faboideae) can be cultivated in all Brazilian regions due to the development of cultivars adapted to diverse environments. Soybean cultivation in the State of São Paulo has shown rapid expansion in the last ten years due to its contribution to the improvement of local production systems, especially in crop succession and the renewal of sugarcane areas (BÁRBARO-TORNELI et al., 2018), reaching a productive area of 1.109 million hectares in the 2019/2020 harvest (CONAB, 2021).

To express the productive potential of a soybean crop, genetic and environmental components and the interaction between them are taken into consideration. (HERRERA et al., 2020). There are different concepts of environment: some authors state that the term should be used for the edaphoclimatic conditions of cultivation (BORÉM; MIRANDA, 2013), whereas others argue that the cultivation environment is the result of biophysical factors, such as sowing times and cultural practices (SILVA et al., 2011).

The most influential cultivation factor is the sowing season (PRABHAKAR et al., 2018) as it relates directly to the time of flowering, maturation, and harvesting of the crop. Theoretically, the optimal sowing date for soybean is between 30 and 45 days before the summer solstice (December 21) as this enables proper plant development during the growing season (FIETZ; RANGEL, 2008). However, most soybean crops are sown outside of this ideal period due to errors in the selection of machines and agricultural implements to optimize agricultural operation, delays in the purchase of agricultural inputs, delays in the onset of rains, and, in particular, a lack of knowledge of the response of cultivars to the time of planting. Regardless of the sown cultivar, the later a soybean crop is sown, the shorter its cycle. Sowing in November is the most suitable for plant development, resulting in higher yields (VAZQUEZ et al., 2019).

Regarding the chemical composition of soybeans, according to Delarmelino-Ferraresi, Villela and Aumonde (2014), the oil and protein contents are genetically attributed, but strongly influenced by environmental factors (temperature and precipitation), mainly during the grain filling period. According to Calçado et al. (2019), there is an interaction between genotype, sowing date, and harvest date indicating that cultivars show variation in the metabolic regulation that determines oil and protein synthesis in the grains.

Adaptability and stability studies enable us to detail the changing behavior of genotypes according to environmental variation. Adaptability reflects how genotypes respond advantageously to environmental stimuli, whereas stability refers to the principle of invariance or predictability of behavior (CRUZ; CARNEIRO; REGAZZI, 2014). The Annicchiarico (1992) method estimates the risk of choosing a genotype. It uses the confidence index as a statistic and expresses the result as a percentage to relate the average performance in the evaluated environments to the performance estimated by an identity model applied to the genotypes. Studies on plant and animal development have used identity models to verify how common equations fit different groups of individuals (CARNEIRO et al., 2014).

For sustainable soybean production, it is important to obtain genotypes with superior grain quality and yield, which show adaptability and stability in different production environments. Consequently, the present study tested the adaptability and stability of 17 soybean genotypes, aiming for high oil and protein contents in the grains, as well as high productivity at different sowing dates in the north-central region of the São Paulo State, Brazil.

\section{MATERIAL AND METHODS}

The study was conducted during the 2015/2016 crop year at the North-central Regional Hub of the Agribusiness Technology Agency of São Paulo (APTA), in Pindorama, São Paulo, Brazil, $\left(21^{\circ}\right.$ $13^{\prime} \mathrm{S}$ and $48^{\circ} 55^{\prime} \mathrm{W}$ ). The climate of the region is classified by Köppen as Aw; defined as tropical humid with a rainy season in the summer and a dry season in the winter. The average maximum temperature, annual rainfall, and annual relative humidity are $22.8{ }^{\circ} \mathrm{C}, 1,390.3 \mathrm{~mm}$ and $71.6 \%$, respectively (FINOTO et al., 2017). Figure 1 shows the monthly rainfall and maximum and minimum temperature averages during the experiment.

The experimental area is a rotation area, and prior to the soybean study, off-season sorghum (2014), peanuts (2014/2015) and corn (2015/2016) were cultivated in the experimental fields. The soil is classified as a moderate eutrophic Argisoil with a sandy/medium texture. The relief of the region is undulating, with altitudes ranging from 498 to $594 \mathrm{~m}$ above sea level. The physicochemical characteristics of the soil at the time of the study were: $\mathrm{pH}=5,0$; M.O. $=11$ g.dm ${ }^{-3} ; \mathrm{H}+\mathrm{Al}=14$ mmolc. $\mathrm{dm}^{-3} ; \mathrm{P}=60$ mg.dm ${ }^{-3} ; \quad \mathrm{K}=3.9$ mmolc. $\mathrm{dm}^{-3} ; \quad \mathrm{Ca}=36$ mmolc. $\cdot \mathrm{dm}^{-3} ; \mathrm{Mg}=6$ mmolc. $\cdot \mathrm{dm}^{-3} ; \mathrm{SB}=45.9$ mmolc. $\mathrm{dm}^{-3} ;$ C.T.C $=59.9$ mmolc. $\mathrm{dm}^{-3} ; \mathrm{V} \%=77 \%$; $\mathrm{B}=0.21 \mathrm{mg} \cdot \mathrm{dm}^{-3} ; \quad \mathrm{Cu}=0.9 \mathrm{mg} \cdot \mathrm{dm}^{-3} ;$ $\mathrm{Fe}=45 \mathrm{mg} \cdot \mathrm{dm}^{-3} ; \mathrm{Mn}=9.4 \mathrm{mg} \cdot \mathrm{dm}^{-3} ;$ and $\mathrm{Zn}=$ $1.1 \mathrm{mg} \cdot \mathrm{dm}^{-3}$. 


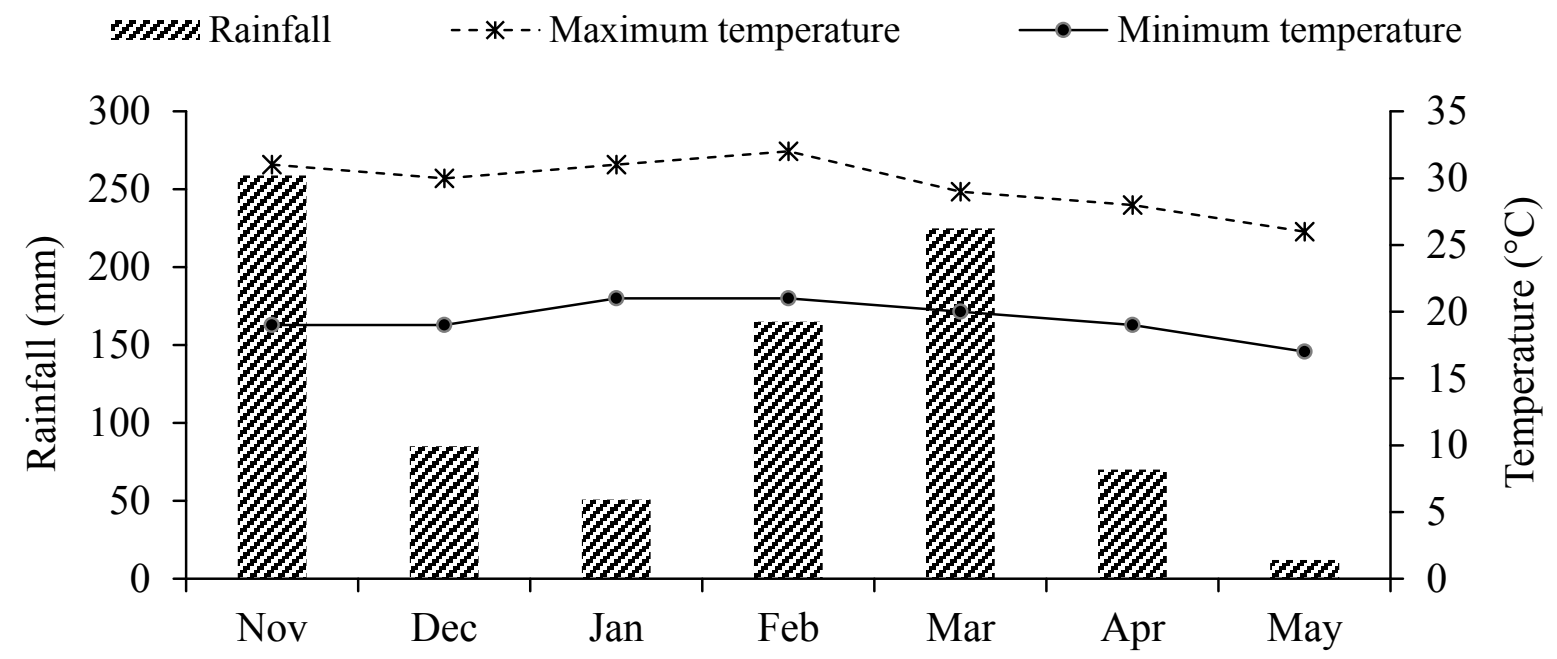

Figure 1. Monthly averages of rainfall, and maximum and minimum temperatures during the soybean experiment in Pindorama in the north-central region of the São Paulo State, Brazil.

A randomized block design was used for the experiment, with three replications arranged in a $17 \times 5$ factorial scheme, with factor A being 17 soybean genotypes (Conquista, CD 223 AP, Elite, Garantia, Bioagro lineage, M-Soy 8400, M-Soy 8001, Nambu, Sambaíba, Esplendor, UFVS 2006, UFVS 2005, UFVTN 102, UVF 18, UFV 16, Valiosa, and Vencedora) and factor $\mathrm{B}$ being five sowing dates $(\mathrm{SD} 1=11 / 03, \mathrm{SD} 2=11 / 20, \mathrm{SD} 3=$ $12 / 07$, SD4 $=12 / 23$, and SD5 $=01 / 09$ ).

Each experimental plot consisted of five $5 \mathrm{~m}$ long rows, spaced $0.90 \mathrm{~m}$ apart, with a density of 14 plants per meter. The plot useful area was $3.6 \mathrm{~m}^{2}$ because only the central portion of each row was harvested and $0.5 \mathrm{~m}$ at the end of each row was discarded.

The experimental area was prepared for cultivation 30 days before sowing by plowing and harrowing twice, followed by the application of $0.5 \mathrm{t} \mathrm{ha}^{-1}$ of dolomitic limestone with $80 \%$ relative power of total neutralization, as guided by the soil analysis results. The planting fertilization was conducted by applying $250 \mathrm{~kg} \mathrm{ha}^{-1}$ of a $04-20-20 \mathrm{~N}$ $\mathrm{P}-\mathrm{K}$ formulation.

The soybean seeds were sown manually and inoculation was performed directly on the sown seeds in the planting furrows, which were sprayed with liquid inoculant (RhizomaxR), containing Bradyrhizobium japonicum SEMIA 5079 and 5080 strains, at a $2.0 \times 109$ cells $\mathrm{mL}^{-1}$ bacterial concentration.

Fifteen days after plant emergence, the surplus plants were thinned to reach a population density of 14 plants per linear meter. Weed control was accomplished by weeding manually twice, and pest and disease control by spraying with croprecommended insecticides and fungicides.
Grain yield was measured after the harvest of soybean plants in each experimental plot. Thereafter, the oil and protein contents in the grains were determined based on the dry mass (DM\%). The oil content was determined by extraction in petroleum ether according to the Goldfish method and the protein content by the Kjeldhal method (BRUM; ARRUDA; REGITANO-D'ARCE, 2009).

After verification of the normality and homogeneity of the data variances using the Lilliefors and Cochram methods, respectively, the data were subjected to individual and joint analysis of variance. Tukey's post-hoc test was used to compare the means at a $5 \%$ probability level; thereafter, according to data dependence, significant regressions were adjusted for each variable studied.

Analysis of the phenotypic adaptability and stability of the genotypes was performed following Annicchiarico (1992). This method estimates the reliability index of a given genotype to perform below the environmental mean estimated from the deviation of the identity regression of the behavior of the genotypes, and is based on the genotypic confidence index. The genotypic confidence index is estimated as: $W_{i(g)}=\hat{\mu}_{i(g)}-Z_{(1-\alpha)} \hat{\sigma}_{Z_{1(g)} \text { considering }}$ both favorable and unfavorable environments, where $\hat{\mu}_{i(g)}$ is the average percentage of genotypes $i ; \hat{\sigma}_{Z_{1(g)}}$ is the standard deviation of the $Z_{\mathrm{ij}}$ values associated with the $i$-th genotype; and $Z_{(1-\alpha)}$ is the percentile of the standard normal distribution function. The confidence coefficient adopted was $75 \%$, that is, $\alpha=$ 0.25 . When the confidence index is decomposed into favorable and unfavorable environments it becomes, as well as a stability measure, a measure of adaptability to these environments. The computer application GENES, which is specialized for 
genetics and statistical analysis, was used (CRUZ, 2013)

\section{RESULTS AND DISCUSSION}

The variances presented normal distributions and data homogeneity, allowing the use of parametric statistical tests without the need for data transformation. In the joint analysis, the homogeneity of the residual variances of the experiments was first evaluated and verified by the ratio between the largest and smallest residual mean square, considered homogeneous when this relation is less than 7.0. In the present study, the values reached for the studied characteristics were: oil content $=2.69$, protein content $=2.28$, and yield $=$ 2.57 .

The coefficients of statistical variation of the studied characteristics were consistently low, ranging from $2.80 \%$ to $7.41 \%$, indicating good precision in controlling the causes of variation of a systematic order in the experiment. The effects of the interaction: Genotypes $(\mathrm{G}) \times$ Sowing dates $(\mathrm{SD})$ were significant at the $1 \%$ probability level, as determined by the $\mathrm{F}$ test for all evaluated characteristics.

The average oil content in the grains ranged from $17.06 \%$ (SD5) to $19.74 \%$ (SD1), with an overall average of $18.23 \%$ between environments (Table 1). Among cultivars, the oil content varied between $22.17 \%$ for the cultivar Sambaíba for SD1 $(11 / 03)$ and $15.01 \%$ for the cultivar CD223 AP sown on SD5 (01/09) (Table 1). The average percentage of oil in soybean seed is reported to be approximately $20 \%$, ranging from $13 \%$ to $28 \%$ (FINOTO et al., 2017). Similar studies, including by Barbosa et al. (2011) and Faria et al. (2018), have revealed soybean oil content ranging from $15.52 \%$ to $22 \%$, in line with the values obtained in the present study.

Table 1. Mean oil content values (\%) in the grains of 17 soybean genotypes planted at five sowing dates (SD1-SD5) during the 2015/2016 agricultural year, in Pindorama, north-central São Paulo State, Brazil.

\begin{tabular}{ccccccc}
\hline & \multicolumn{5}{c}{ Sowing dates } \\
\cline { 2 - 6 } Genotypes & SD1 & SD2 & SD3 & SD4 & SD5 \\
& $(11 / 03)$ & $(11 / 20)$ & $(12 / 07)$ & $(12 / 23)$ & $(01 / 09)$ & Mean \\
\hline M-Soy 8001 & $20.21 \mathrm{Aa}$ & $20.70 \mathrm{Aab}$ & $20.33 \mathrm{Aa}$ & $19.23 \mathrm{Aa}$ & $18.26 \mathrm{Aa}$ & 19.75 \\
UFV 18 & $21.11 \mathrm{Aa}$ & $20.18 \mathrm{ABabc}$ & $17.55 \mathrm{Bab}$ & $18.62 \mathrm{ABa}$ & $17.75 \mathrm{Ba}$ & 19.04 \\
Garantia & $19.46 \mathrm{ABa}$ & $20.74 \mathrm{Aa}$ & $17.01 \mathrm{Bab}$ & $19.19 \mathrm{ABa}$ & $18.17 \mathrm{ABa}$ & 18.91 \\
Sambaiba & $22.17 \mathrm{Aa}$ & $17.89 \mathrm{Babc}$ & $17.68 \mathrm{Bab}$ & $18.47 \mathrm{Ba}$ & $17.96 \mathrm{Ba}$ & 18.83 \\
UFVTN 102 & $20.76 \mathrm{Aa}$ & $17.8 \mathrm{Aabc}$ & $18.04 \mathrm{Aab}$ & $18.26 \mathrm{Aa}$ & $18.37 \mathrm{Aa}$ & 18.65 \\
UFV 16 & $19.82 \mathrm{Aa}$ & $17.89 \mathrm{Aabc}$ & $17.42 \mathrm{Aab}$ & $18.71 \mathrm{Aa}$ & $17.85 \mathrm{Aa}$ & 18.34 \\
M-Soy 8400 & $18.96 \mathrm{Aa}$ & $18.67 \mathrm{Aabc}$ & $16.86 \mathrm{Aab}$ & $19.25 \mathrm{Aa}$ & $17.68 \mathrm{Aa}$ & 18.28 \\
Esplendor & $19.93 \mathrm{Aa}$ & $18.03 \mathrm{Aabc}$ & $17.75 \mathrm{Aab}$ & $18.24 \mathrm{Aa}$ & $17.08 \mathrm{Aa}$ & 18.21 \\
Valiosa & $19.12 \mathrm{Aa}$ & $18.55 \mathrm{Aabc}$ & $17.91 \mathrm{Aab}$ & $18.09 \mathrm{Aa}$ & $16.83 \mathrm{Aa}$ & 18.10 \\
UFVS 2005 & $19.23 \mathrm{ABa}$ & $19.71 \mathrm{Aabc}$ & $16.60 \mathrm{Bab}$ & $18.17 \mathrm{ABa}$ & $16.62 \mathrm{Ba}$ & 18.07 \\
Conquista & $19.14 \mathrm{Aa}$ & $18.29 \mathrm{Aabc}$ & $18.00 \mathrm{Aab}$ & $18.32 \mathrm{Aa}$ & $16.42 \mathrm{Aa}$ & 18.03 \\
Nambu & $19.02 \mathrm{Aa}$ & $18.97 \mathrm{Aabc}$ & $16.22 \mathrm{Ab}$ & $18.83 \mathrm{Aa}$ & $16.26 \mathrm{Aa}$ & 17.86 \\
Elite & $18.99 \mathrm{Aa}$ & $18.29 \mathrm{ABabc}$ & $15.79 \mathrm{Bb}$ & $18.51 \mathrm{ABa}$ & $17.41 \mathrm{ABa}$ & 17.80 \\
UFVS 2006 & $21.33 \mathrm{Aa}$ & $16.45 \mathrm{Bc}$ & $17.13 \mathrm{Bab}$ & $17.79 \mathrm{Ba}$ & $16.24 \mathrm{Ba}$ & 17.79 \\
CD 223 AP & $19.31 \mathrm{Aa}$ & $17.09 \mathrm{ABabc}$ & $17.95 \mathrm{ABab}$ & $18.49 \mathrm{Aa}$ & $15.01 \mathrm{Ba}$ & 17.57 \\
Vencedora & $18.41 \mathrm{Aa}$ & $18.53 \mathrm{Aabc}$ & $17.51 \mathrm{Aab}$ & $16.58 \mathrm{Aa}$ & $15.91 \mathrm{Aa}$ & 17.39 \\
Bioagro lineage & $18.67 \mathrm{Aa}$ & $16.87 \mathrm{Abc}$ & $17.70 \mathrm{Aab}$ & $17.37 \mathrm{Aa}$ & $16.15 \mathrm{Aa}$ & 17.35 \\
\hline Mean & 19.74 & 18.51 & 17.50 & 18.36 & 17.06 & 18.23 \\
\hline
\end{tabular}

Means followed by the same letter, lowercase in columns and uppercase in rows, do not differ by Tukey's test $(P<0.05)$.

*Tukey's HSD at 5\% probability between sowing dates $=3.03$ and between genotypes $=3.85$.

Considering the oil content values of the cultivars averaged across all sowing dates, only the genotypes M-Soy 8001, UFV 18, and Garantia presented mean grain oil content values above $18.9 \%$. The mean grain oil content for each sowing date, averaged across cultivars, varied between $19.74 \%$ for seeds sown in the first half of November and $17.06 \%$ for seeds sown in the first half of January (67 days later).

Of the 17 genotypes evaluated, 10 did not 
show significant responses to the delay in sowing, whereas the others showed a significant decrease in oil content in relation to sowing time. This finding indicates that the 10 genotypes showed superior physiological or biochemical responses to variations in temperature and water availability associated with sowing at different times. This may be due to higher photosynthetic efficiency of these genotypes, related not only to higher yields but also to higher energy availability for the plants, reducing the climatic influence on the chemical composition of the grains (NAOE et al., 2021).

It is noteworthy that the Sambaíba and UFVS 2006 genotypes showed significant reductions in oil content from SD2, with a 17-day delay. Barbosa et al. (2011) observed a trend in oil content reduction with a delay in sowing time, which was probably due to lower temperatures and higher rainfall before the grain maturation period. However, Calçado et al. (2019) observed very different behavior between the genotypes, with no clear pattern of an increase or decrease in oil content with delayed sowing.

In the present study, the earliest sowing date
(SD1), produced the best oil content results for all genotypes. The sowing time-sensitive genotypes showed significant differences in oil contents only for SD2 (11/20) and SD3 (12/07), when the life cycle and, consequently, the harvesting period were decisive, in addition to the genetic sensitivity to environmental stresses in the grain-filling period. The genotypes did not differ in oil content when sown on SD4 (23/23) and SD5 (01/09).

Figure 2 shows the trends in grain oil content for the UFV 18 and UFVS 2005 genotypes with regressions that were significant for a linear model showing a decrease in oil content with a delay in sowing time, in addition to the identity curve based on these regressions after likelihood tests. These trends are likely to reflect the response of these genotypes to the low rainfall during the initial and final phases of the crop cycle (Figure 1), probably resulting in a lower nutrient transport efficiency, which may have decreased the concentration of oil in the grains, as observed in a study by Carvalho et al. (2021).

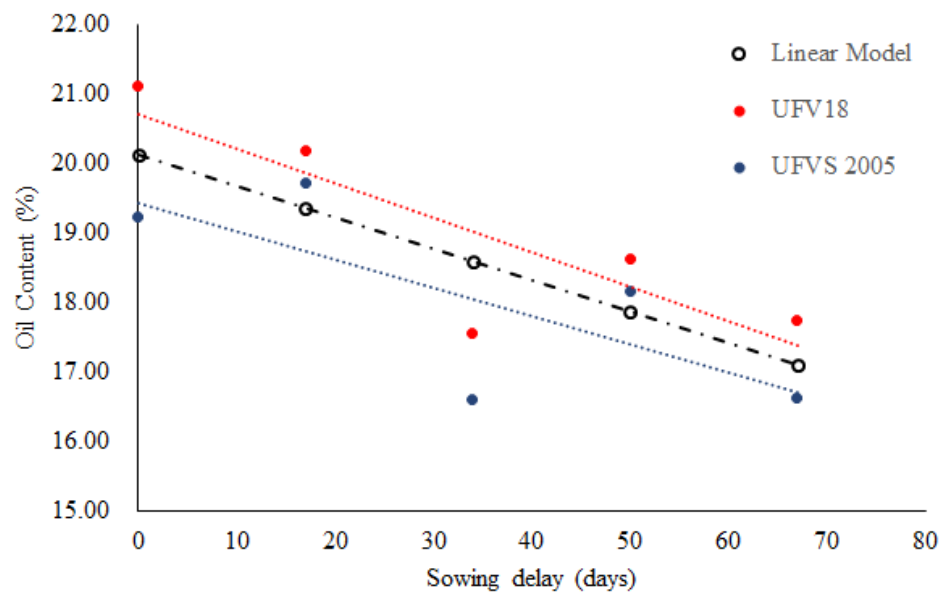

Figure 2. Relationship between the number of days of delay from the first sowing date (November 7th) and the oil content in the grains (\%) of two soybean genotypes grown during the 2015/2016 agricultural year in Pindorama, north-central São Paulo State, Brazil. Identity linear model for the oil content of these genotypes: $Y=20.12-0.045 x\left(R^{2}=94.73\right)$.

Figure 3 shows the trends in grain oil content of soybean genotypes with datasets that generated cubic model equations. There was no model identity for these genotypes due to the large number of genotypes and the discrepancy between their curves. However, Figure 3 shows that there was a tendency to a decrease in the oil content of the grains produced by these genotypes in response to delayed sowing.

There was a general tendency for the genotypes to show a decrease in oil content with a delay in sowing, although for most of them, this trend was not significant. The difference among the genotypes, as shown by the curves in Figure 3, indicates how intense is the genetic component of oil content in grains, and the observed downward trend suggests some environmental effect. In the western region of Paraná, Albrecht et al. (2008) observed different response capacities of the oil content at the sowing time with a slight tendency to decrease as the sowing time was extended. The different responses may have been due to high temperatures associated with low precipitation occurring during the reproductive stages of the crop. Calçado et al. (2019) observed the same response when evaluating sowing dates and harvest periods of soybean cultivars in Tocantins State. They found a higher oil content in grains produced from the earliest sowing date, supporting the results of the present study. 


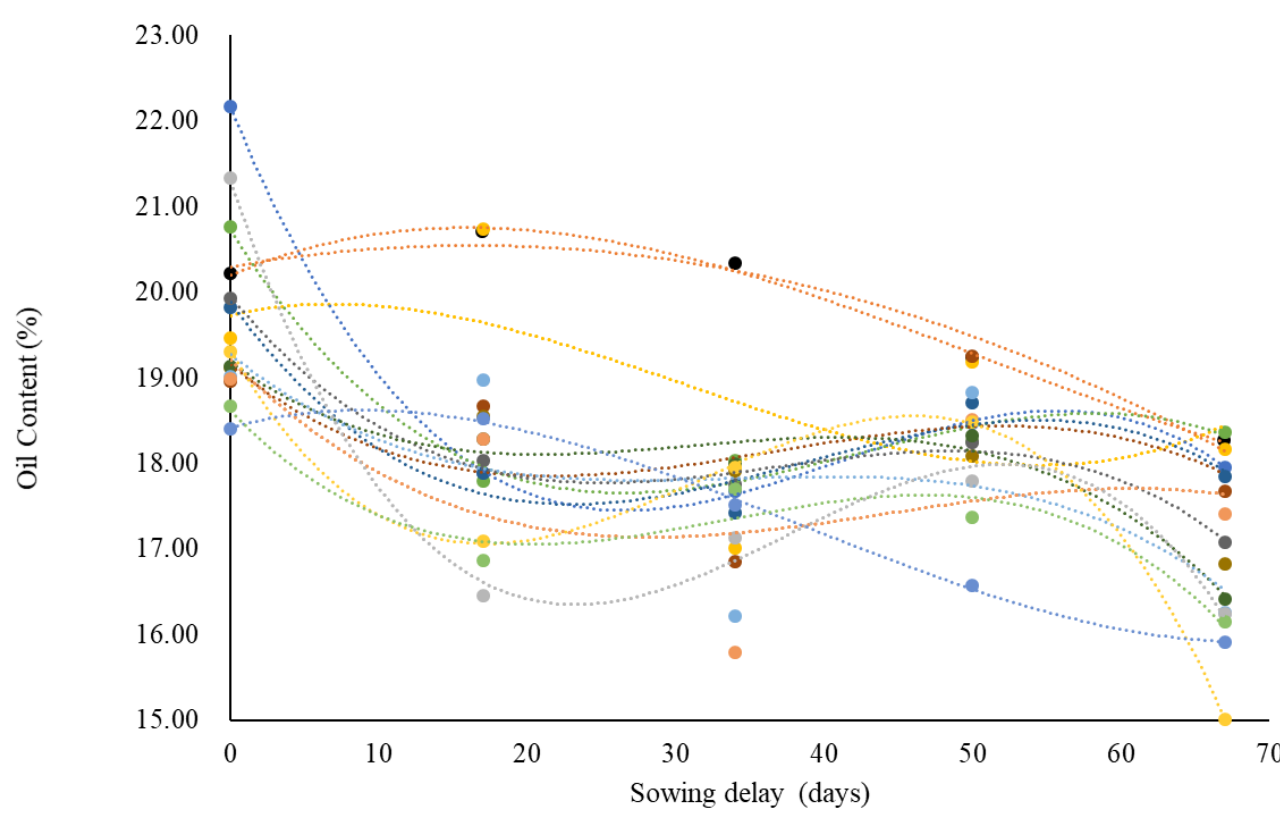

- M-Soy 8001

- Garantia

- Sambaiba

- UFVTN 102

- UFV 16

- M-Soy 8400

- Esplendor

- Valiosa

- Conquista

- Nambu

- Elite

- UFVS 2006

- CD $223 \mathrm{AP}$ Vencedora

- Bioagro lineage

Figure 3. Relationship between the number of days of delay from the first sowing date (November 7th) and the oil content in the grains (\%) of soybean genotypes grown during the 2015/2016 agricultural year in Pindorama, north-central São Paulo State, Brazil.

Table 2 shows the estimates of the average oil content in soybeans and the confidence index decomposition for environments, in this case, sowing times, favorable and unfavorable according to the environmental indexes. Based on the confidence or recommendation index for the oil content in the grains (Table 2), the genotypes M-Soy 8001, UFV 18, Garantia, Sambaíba, and UFVTN 102 appeared to be the best adapted to the different sowing dates as they presented higher overall confidence indexes
(106.9; 103.3; 102.1; 101.6 and 101.1 , respectively) than those estimated by the identity regression of the model (100) when considering its performance on all sowing dates. The confidence index decomposed between favorable (SD1, SD2, and SD4) and unfavorable (SD3 and SD5) sowing dates presented the genotypes M-Soy 8001, UFV 18, Garantia, and Sambaíba as better than estimated by the identity model and also as the more stable genotypes.

Table 2. Estimates of the means of oil content $(\%)^{*}$ and the confidence index $(\mathrm{Wi})$ according to the method of Annicchiarico (1992). The confidence index was decomposed between favorable and unfavorable sowing dates. A total of 17 soybean genotypes were grown during the 2015/2016 agricultural year in Pindorama, north-central São Paulo State, Brazil.

\begin{tabular}{|c|c|c|c|c|c|c|}
\hline \multirow[b]{2}{*}{ Genotypes } & \multicolumn{2}{|c|}{ General } & \multicolumn{2}{|c|}{ Favorable } & \multicolumn{2}{|c|}{ Unfavorable } \\
\hline & Mean & $W i$ & Mean & $W i$ & Mean & $W i$ \\
\hline M-Soy 8001 & 19.75 & 106.9 & 20.05 & 104.97 & 19.29 & 109.8 \\
\hline UFV 18 & 19.04 & 103.3 & 19.97 & 104.72 & 17.65 & 101.5 \\
\hline Garantia & 18.91 & 102.1 & 19.80 & 103.20 & 17.59 & 100.1 \\
\hline Sambaiba & 18.84 & 101.6 & 19.51 & 100.96 & 17.82 & 102.4 \\
\hline UFVTN 102 & 18.65 & 101.1 & 18.94 & 99.03 & 18.21 & 104.5 \\
\hline UFV 16 & 18.34 & 99.8 & 18.81 & 98.91 & 17.64 & 101.1 \\
\hline M-Soy 8400 & 18.28 & 99.2 & 18.96 & 99.37 & 17.27 & 98.6 \\
\hline Esplendor & 18.21 & 99.4 & 18.73 & 98.75 & 17.41 & 100.5 \\
\hline Valiosa & 18.10 & 98.8 & 18.59 & 98.07 & 17.37 & 99.8 \\
\hline UFVS 2005 & 18.07 & 97.8 & 19.04 & 99.62 & 16.61 & 95.7 \\
\hline Conquista & 18.04 & 98.2 & 18.59 & 98.13 & 17.21 & 98.3 \\
\hline Nambu & 17.86 & 96.7 & 18.94 & 99.49 & 16.24 & 93.5 \\
\hline Elite & 17.80 & 96.3 & 18.60 & 97.97 & 16.60 & 93.9 \\
\hline UFVS 2006 & 17.79 & 95.5 & 18.53 & 95.32 & 16.69 & 96.1 \\
\hline CD $223 \mathrm{AP}$ & 17.57 & 94.6 & 18.30 & 95.77 & 16.48 & 92.5 \\
\hline Vencedora & 17.39 & 94.2 & 17.84 & 93.17 & 16.71 & 95.4 \\
\hline Bioagro lineage & 17.35 & 94.2 & 17.64 & 92.89 & 16.93 & 96.7 \\
\hline
\end{tabular}

$*$ Alfa $=0.25 ; Z(1-$ alfa $)=0.2734$. 
The protein content in the soybean grains ranged from $38.98 \%$ for the UFVS 2006 genotype at SD2 $(11 / 20)$ to $49.51 \%$ for the Bioagro lineage at SD5 (01/09) (Table 3). Among the genotypes, the highest average grain protein content was produced by the Bioagro lineage with an overall average of $48.55 \%$, followed by the CD 223 AP genotype with $45.27 \%$. Genotypes that produce a high grain protein content are valuable due to the extensive use of soy protein in human food as a vegetable protein of similar quality to animal protein. Albrecht et al. (2008) found soybean grain protein contents close to $40 \%$, whereas in the present study, all the genotypes produced higher protein content averages, with more than $49 \%$ in the Bioagro lineage. According to Bueno et al. (2017), the Soybean Quality Improvement Program/BIOAGRO-UFV has, over the years, developed productive soybean varieties with a high grain protein concentration (above 44\%) from which it would be possible to produce a protein concentrate of approximately $70 \%$.
Regarding the sowing dates, the highest protein contents were found in grains produced by plants sown on SD1 (11/03) and SD5 (01/09). Studies conducted by Albrecht et al. (2008) and Hackenhaar et al. (2019) identified an increase in protein content with delayed sowing and related it to reduced water availability during the reproductive period. However, in the present study, an increase in protein content occurred only after 67 days of delay in sowing.

In the present study, there were differences in the degree of sensitivity of the genotypes to different sowing dates, which affected the protein content of the grains. The Bioagro, Garantia, Esplendor, Conquista, and UFVS 2005 genotypes appeared to be the least sensitive to sowing delays. Calçado et al. (2019) have reported similar results. When comparing the sowing dates independently, some of the genotypes showed similar responses between the sowing times, whereas others showed a greater variation in protein content with delay in sowing.

Table 3. Mean values of grain protein content (\%) of 17 soybean cultivars sown on five different sowing dates (SD1-SD5) during the 2015/2016 agricultural year in Pindorama, north-central São Paulo State, Brazil

\begin{tabular}{|c|c|c|c|c|c|c|}
\hline \multirow[b]{2}{*}{ Genotypes } & \multicolumn{6}{|c|}{ Sowing Dates } \\
\hline & $\begin{array}{c}\text { SD1 } \\
(11 / 03)\end{array}$ & $\begin{array}{c}\text { SD2 } \\
(11 / 20)\end{array}$ & $\begin{array}{c}\text { SD3 } \\
(12 / 07)\end{array}$ & $\begin{array}{c}\text { SD4 } \\
(12 / 23)\end{array}$ & $\begin{array}{c}\text { SD5 } \\
(01 / 09)\end{array}$ & Mean \\
\hline Bioagro lineage & $48.66 \mathrm{Aa}$ & $48.76 \mathrm{Aa}$ & $47.01 \mathrm{Aa}$ & $48.81 \mathrm{Aa}$ & $49.51 \mathrm{Aa}$ & 48.55 \\
\hline CD 223 AP & 47.89Aab & $46.92 \mathrm{ABa}$ & $43.63 \mathrm{Cab}$ & $43.32 \mathrm{Cb}$ & $44.59 \mathrm{BCb}$ & 45.27 \\
\hline Garantia & 43.35Acd & $43.04 \mathrm{Ab}$ & $42.25 \mathrm{Abc}$ & $43.62 \mathrm{Ab}$ & $44.81 \mathrm{Ab}$ & 43.41 \\
\hline UFVTN 102 & $44.54 \mathrm{Abc}$ & $41.61 \mathrm{Bbc}$ & $43.19 \mathrm{ABb}$ & $42.78 \mathrm{ABb}$ & $44.72 \mathrm{Ab}$ & 43.37 \\
\hline Vencedora & 43.7Acd & $43.23 \mathrm{ABb}$ & $40.84 \mathrm{Bbc}$ & $44.04 \mathrm{Ab}$ & $42.67 \mathrm{ABbc}$ & 42.9 \\
\hline Valiosa & 43.32ABcd & 41.67ABbc & $40.7 \mathrm{Bbc}$ & $43.29 \mathrm{ABb}$ & $44.17 \mathrm{Abc}$ & 42.63 \\
\hline Esplendor & 42.71Acd & $40.8 \mathrm{Abc}$ & 41.77Abc & $43.39 \mathrm{Ab}$ & $43.07 \mathrm{Abc}$ & 42.35 \\
\hline Conquista & 42.98Acd & $40.71 \mathrm{Abc}$ & $41.53 \mathrm{Abc}$ & $41.85 \mathrm{Ab}$ & $42.64 \mathrm{Abc}$ & 41.94 \\
\hline UFVS 2006 & 41.45ABCcd & $38.98 \mathrm{Cc}$ & $40.72 \mathrm{BCbc}$ & $43.18 \mathrm{ABb}$ & 43.7Abc & 41.61 \\
\hline M-Soy 8400 & 42.99Acd & 41.59ABbc & $39.74 \mathrm{Bc}$ & $41.24 \mathrm{ABb}$ & $41.95 \mathrm{ABbc}$ & 41.5 \\
\hline Nambu & 41.86Acd & 40.76ABbc & $39.01 \mathrm{Bc}$ & $42.69 \mathrm{Ab}$ & $42.59 \mathrm{Abc}$ & 41.38 \\
\hline Elite & 41.9ABcd & $39.41 \mathrm{Bc}$ & $40.35 \mathrm{Bbc}$ & $43.45 \mathrm{Ab}$ & 41.76ABbc & 41.37 \\
\hline M-Soy 8001 & 42.61Acd & $40.59 \mathrm{ABbc}$ & $39.66 \mathrm{Bc}$ & $41.32 \mathrm{ABb}$ & $42.22 \mathrm{ABbc}$ & 41.28 \\
\hline Sambaiba & $40.78 \mathrm{ABd}$ & $39.44 \mathrm{Bc}$ & $40.35 \mathrm{ABbc}$ & $42.34 \mathrm{Ab}$ & $41.81 \mathrm{ABbc}$ & 40.94 \\
\hline UFV 16 & $41.81 \mathrm{ABcd}$ & $39.53 \mathrm{Bc}$ & $39.17 \mathrm{Bc}$ & $41.23 \mathrm{ABb}$ & $42.65 \mathrm{Abc}$ & 40.88 \\
\hline UFVS 2005 & 41.25Acd & $41.14 \mathrm{Abc}$ & $39.58 \mathrm{Ac}$ & $40.71 \mathrm{Ab}$ & 41.12Ac & 40.76 \\
\hline UFV 18 & $40.36 \mathrm{ABd}$ & $39.16 \mathrm{Bc}$ & $39.57 \mathrm{Bc}$ & $42.55 \mathrm{Ab}$ & $41.73 \mathrm{ABbc}$ & 40.67 \\
\hline Mean & 43.07 & 41.61 & 41.12 & 42.93 & 43.28 & 42.4 \\
\hline
\end{tabular}

Means followed by the same letter, lowercase in columns and uppercase in rows, do not differ by Tukey's test $(P<0.05)$.

${ }^{*}$ Tukey's HSD at $5 \%$ probability between sowing dates $=2.66$ and between genotypes $=3.38$.

Although some standard identity models to define the common protein content responses of the genotypes to the five sowing dates were established, none of the genotypes presented a linear equation.
Figure 4 shows the trends in protein contents of the genotypes with datasets that generated significant quadratic model equations, as well as the identity model of this group of seven genotypes. The Bioagro 
lineage, selected for superior grain quality, outperformed the other genotypes, not being correctly represented by the identity model.

There was a decrease in protein content up to approximately 34 days of delay in sowing, followed by an increase. This trend indicates that later plantings tended to concentrate higher levels of protein in the grains, most likely due to greater environmental stresses, especially water deficit (FINOTO et al., 2017; CALÇADO et al., 2019). Lopes et al. (2016) conducted a study of the protein content of soybean cultivars in response to different sowing times and verified higher levels produced by plants sown late, probably due to low rainfall during the grain filling phase.

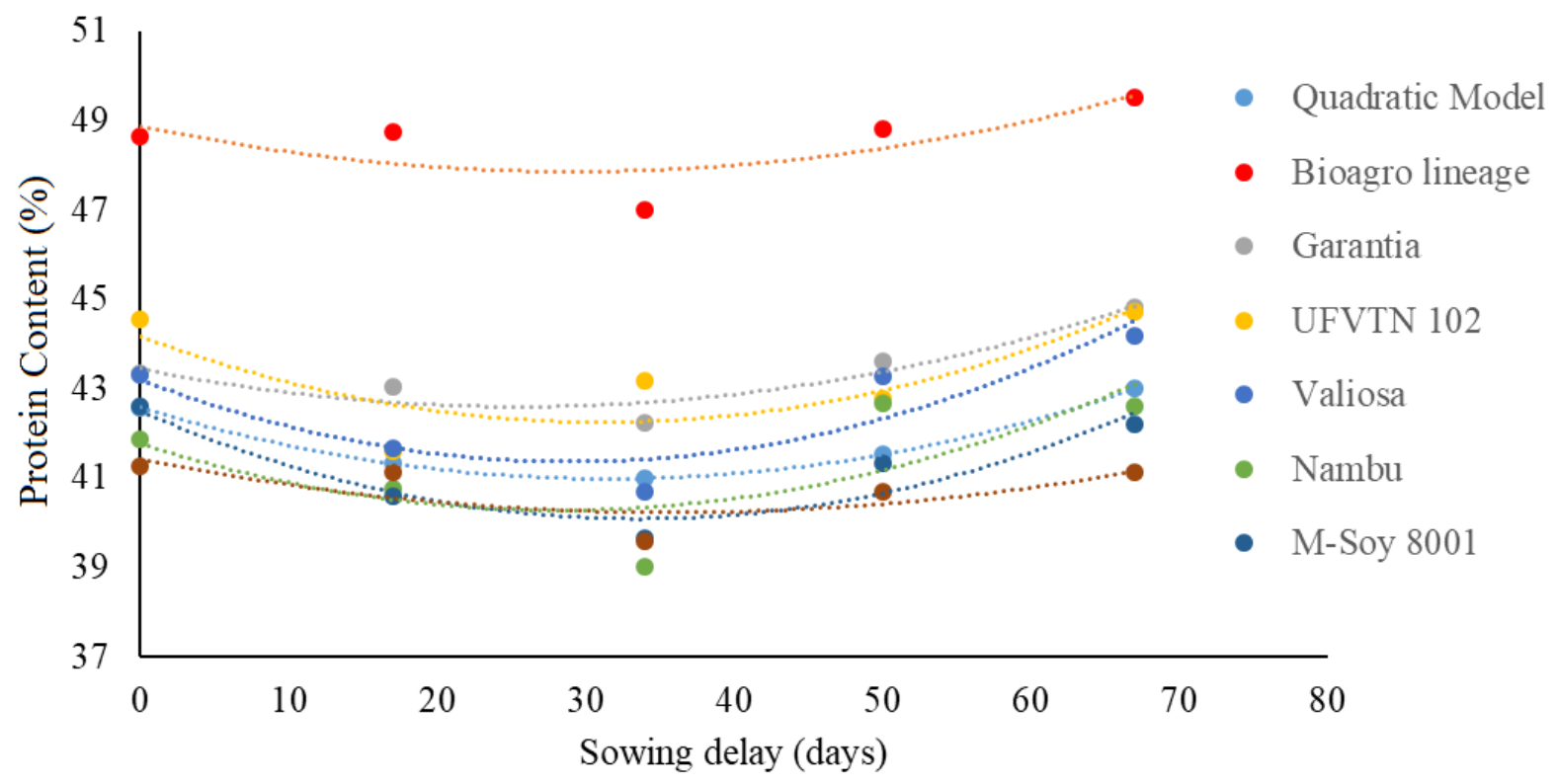

Figure 4. Relationship between the number of days of delay from the first sowing date (November 7 th) and the protein content in grains (\%) of soybean genotypes grown during the 2015/2016 agricultural year in Pindorama, north-central São Paulo State, Brazil. Quadratic identity model for protein content of genotypes: $\mathrm{Y}=42.58-0.101 \mathrm{x}+0.0016 \mathrm{x}^{2}\left(\mathrm{R}^{2}=99.92\right)$.

Figure 5 shows the genotypes with datasets that generated cubic model equations. The CD 223 AP genotype showed a different trend in protein content from the other genotypes, not being represented by the proposed cubic identity model. The protein contents of the other genotypes, despite significantly adjusting to the cubic model, showed the same trend of an initial decrease followed by an increase in response to delay in sowing. According to Delarmelino-Ferraresi, Villela and Aumonde (2014), as it is not possible to explain the difference and variation in grain protein contents in soybean at different sowing dates on the basis of specific biotic factors; however, rainfall distribution during the grain-filling period may account for the protein content dynamics.

Table 4 presents the estimated mean grain protein contents in soybeans and the confidence index decomposition for environments, in this case, sowing times, favorable and unfavorable according to the environmental indexes. Based on the confidence or recommendation index for the protein content in the grains, the genotypes Bioagro, CD 223 AP, Garantia, UFVTN 102, Vencedora, and Valiosa appeared to be the best adapted to the different sowing dates with confidence indexes higher than that estimated by the identity model $(114.1 ; 105.4$;
102.1; 101.6; 100.6 and 100.2, respectively). The confidence index, categorized into favorable (SD1, SD4 and SD5) and unfavorable (SD2 and SD3) sowing dates, except for the Valiosa genotype, shows the genotypes that performed better than estimated by the identity model; these are also considered the more stable genotypes.

The results of the present study, showing the trends in oil and protein contents in response to sowing date, expand the framework of information regarding the behavior of the soybean genotypes used in Brazil. Although there was variation among the 17 genotypes used in this study, they were all superior to the seven commercial soybean cultivars tested by Faria et al. (2018) in terms of protein content. However, the same seven cultivars tested by these authors were superior to all the genotypes tested in the present study in terms of oil contents. These findings suggest a possible negative correlation between the grain oil and protein contents observed in this study, suggesting that the edaphoclimatic conditions during the experiment favored the increase of protein in the grains and negatively affected the oil content. Similar soybean responses have been reported by DelarmelinoFerraresi, Villela and Aumonde (2014). 


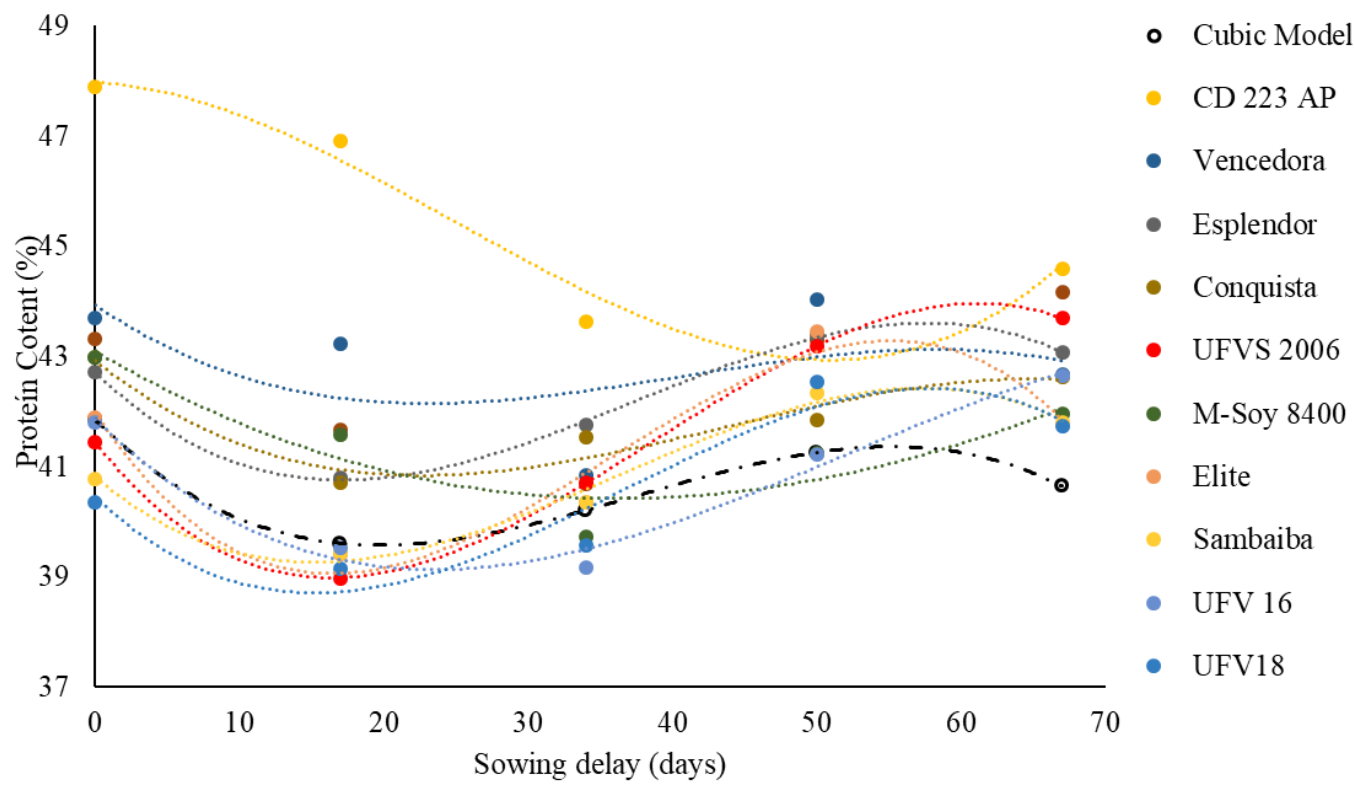

Figure 5. Relationship between the number of days of delay from the first sowing date (November 7th) and the protein content in grains (\%) of soybean genotypes grown during the 2015/2016 agricultural year in Pindorama, north-central São Paulo State, Brazil. Cubic identity model for protein content of genotypes: $Y=41.86-0.262 \mathrm{x}+0.009 \mathrm{x}^{2}-0.00008 \mathrm{x}^{3}\left(\mathrm{R}^{2}=\right.$ 99.96).

Table 4. Estimates of the means of protein content $(\%)^{*}$ and the confidence index $(\mathrm{Wi})$ according to the method of Annicchiarico (1992). The confidence index was decomposed between favorable and unfavorable environments (sowing dates). A total of 17 soybean genotypes were grown during the 2015/2016 agricultural year in Pindorama, north-central São Paulo State, Brazil.

\begin{tabular}{|c|c|c|c|c|c|c|}
\hline \multirow[b]{2}{*}{ Genotypes } & \multicolumn{2}{|c|}{ General } & \multicolumn{2}{|c|}{ Favorable } & \multicolumn{2}{|c|}{ Unfavorable } \\
\hline & Mean & $\overline{W i}$ & Mean & $\overline{W i}$ & Mean & $\overline{W i}$ \\
\hline Bioagro lineage & 48.55 & 114.1 & 48.99 & 113.5 & 47.89 & 115.2 \\
\hline $\mathrm{CD} 223 \mathrm{AP}$ & 45.27 & 105.4 & 45.27 & 103.6 & 45.28 & 108.1 \\
\hline Garantia & 43.42 & 102.1 & 43.93 & 101.5 & 42.65 & 103.0 \\
\hline UFVTN 102 & 43.37 & 101.6 & 44.01 & 101.5 & 42.40 & 101.6 \\
\hline Vencedora & 42.90 & 100.6 & 43.47 & 100.3 & 42.04 & 100.7 \\
\hline Valiosa & 42.63 & 100.2 & 43.59 & 100.9 & 41.19 & 99.3 \\
\hline Esplendor & 42.35 & 99.5 & 43.06 & 99.6 & 41.29 & 99.1 \\
\hline Conquista & 41.94 & 98.5 & 42.49 & 98.3 & 41.12 & 98.8 \\
\hline UFVS 2006 & 41.61 & 97.3 & 42.78 & 98.5 & 39.85 & 95.3 \\
\hline M-Soy 8400 & 41.50 & 97.4 & 42.06 & 97.1 & 40.67 & 97.7 \\
\hline Nambu & 41.38 & 97.1 & 42.38 & 98.0 & 39.89 & 95.8 \\
\hline Elite & 41.38 & 96.9 & 42.37 & 97.6 & 39.88 & 95.8 \\
\hline M-Soy 8001 & 41.28 & 97.1 & 42.05 & 97.2 & 40.12 & 96.8 \\
\hline Sambaiba & 40.95 & 96.1 & 41.64 & 96.1 & 39.90 & 95.8 \\
\hline UFV 16 & 40.88 & 96.0 & 41.90 & 96.9 & 39.35 & 95.1 \\
\hline UFVS 2005 & 40.76 & 95.7 & 41.03 & 95.1 & 40.36 & 97.1 \\
\hline UFV 18 & 40.67 & 95.3 & 41.55 & 95.7 & 39.37 & 94.8 \\
\hline
\end{tabular}

$*$ Alfa $=0.25 ; Z(1-$ alfa $)=0.2734$

The average grain yield varied from $1,494 \mathrm{~kg} \mathrm{ha}^{-1}$ for the Bioagrolineage plants sown on SD5 $(01 / 09)$ to $4,753 \mathrm{~kg} \mathrm{ha}^{-1}$ for the Nambu genotype sown on SD3 (12/07) (Table 5). Considering the means of all sowing dates, the most productive genotypes were the cultivars: Elite, Nambu, and Garantia, which produced $3,525 \mathrm{~kg} \mathrm{ha}^{-1} ; 3,406 \mathrm{~kg} \mathrm{ha}^{-1}$; and 3,398 $\mathrm{kg} \mathrm{ha}^{-1}$ of grain, respectively. The yield values of the three most productive genotypes were above the national average for the 2020/2021 crop year, which was $3,379 \mathrm{~kg} \mathrm{ha}^{-1}$ (CONAB, 2021). These genotypes show promise for cultivation in the study region when the goals are not to obtain high oil and protein contents in the grains, due to the low contents shown by both. These results even surpass the average of some standard cultivars grown at different study sites, and, according to Barbosa et al. (2011) evidence possible genetic gain from genotype interaction with the cultivation environment. 
E. L. FINOTO et al.

Table 5. Average grain yield values $\left(\mathrm{kg} \mathrm{ha}^{-1}\right)$ of 17 soybean genotypes sown at five different sowing times during the 2015/2016 agricultural year in Pindorama, north-central São Paulo State, Brazil.

\begin{tabular}{ccccccc}
\hline & \multicolumn{5}{c}{ Sowing dates } \\
\cline { 2 - 6 } Genotypes & SD1 & SD2 & SD3 & SD4 & SD5 \\
& $(11 / 03)$ & $(11 / 20)$ & $(12 / 07)$ & $(12 / 23)$ & $(01 / 09)$ & Mean \\
\hline Elite & $4444 \mathrm{Aa}$ & $4032 \mathrm{Bab}$ & $4512 \mathrm{Aab}$ & $2377 \mathrm{Ccdef}$ & $2259 \mathrm{Cabc}$ & 3525 \\
Nambu & $3630 \mathrm{Bbc}$ & $3954 \mathrm{Bab}$ & $4753 \mathrm{Aa}$ & $2370 \mathrm{Ccdef}$ & $2321 \mathrm{Cab}$ & 3406 \\
Garantia & $3908 \mathrm{Ab}$ & $3843 \mathrm{Aabc}$ & $3833 \mathrm{Acd}$ & $3636 \mathrm{Aa}$ & $1772 \mathrm{Bcde}$ & 3398 \\
Sambaiba & $3333 \mathrm{Bcde}$ & $3324 \mathrm{Bcde}$ & $4216 \mathrm{Abc}$ & $2870 \mathrm{Cbc}$ & $2130 \mathrm{Dabcd}$ & 3175 \\
Valiosa & $3458 \mathrm{Bbcd}$ & $4315 \mathrm{Aa}$ & $3241 \mathrm{Befg}$ & $2685 \mathrm{Cbcd}$ & $1864 \mathrm{Dbcde}$ & 3113 \\
M-Soy 8400 & $3236 \mathrm{Bcdef}$ & $3222 \mathrm{Bde}$ & $4118 \mathrm{Abc}$ & $2648 \mathrm{Cbcd}$ & $2111 \mathrm{Dacd}$ & 3067 \\
UFV 18 & $3185 \mathrm{Bcdef}$ & $3153 \mathrm{Bcdef}$ & $3741 \mathrm{Acde}$ & $2623 \mathrm{Cbcd}$ & $2432 \mathrm{Ca}$ & 3027 \\
M-Soy 8001 & $3356 \mathrm{Acd}$ & $3551 \mathrm{Abcd}$ & $3444 \mathrm{Adef}$ & $2481 \mathrm{Bbcde}$ & $2043 \mathrm{Cabcd}$ & 2975 \\
Vencedora & $3065 \mathrm{Bdefg}$ & $3764 \mathrm{Abc}$ & $2914 \mathrm{Bghi}$ & $2932 \mathrm{Bb}$ & $1833 \mathrm{Cbcde}$ & 2902 \\
Conquista & $3056 \mathrm{Adefg}$ & $3227 \mathrm{Ade}$ & $3408 \mathrm{Adefg}$ & $2327 \mathrm{Bdef}$ & $1957 \mathrm{Babcde}$ & 2795 \\
UFVTN 102 & $2815 \mathrm{ABefgh}$ & $2810 \mathrm{Befg}$ & $3753 \mathrm{Acde}$ & $2457 \mathrm{Bbcde}$ & $1883 \mathrm{Cbcde}$ & 2744 \\
Esplendor & $2773 \mathrm{Bfgh}$ & $3000 \mathrm{Bef}$ & $3543 \mathrm{Adef}$ & $2253 \mathrm{Cdefg}$ & $2062 \mathrm{Cabcd}$ & 2726 \\
UFVS 2005 & $2583 \mathrm{Bgh}$ & $2375 \mathrm{BCgh}$ & $3130 \mathrm{Afgh}$ & $2043 \mathrm{CDefg}$ & $1963 \mathrm{Dabcde}$ & 2419 \\
UFV 16 & $2815 \mathrm{Befgh}$ & $2463 \mathrm{Agh}$ & $2475 \mathrm{Aij}$ & $1741 \mathrm{Bcde}$ & $1741 \mathrm{Bcde}$ & 2247 \\
UFVS 2006 & $2522 \mathrm{ABh}$ & $2639 \mathrm{Afg}$ & $2222 \mathrm{Bj}$ & $1790 \mathrm{Cg}$ & $1513 \mathrm{Ce}$ & 2137 \\
CD 223 AP & $1968 \mathrm{Bi}$ & $2407 \mathrm{Agh}$ & $2654 \mathrm{Ahij}$ & $1889 \mathrm{Bfg}$ & $1691 \mathrm{Bde}$ & 2122 \\
Linhagem Bioagro & $1991 \mathrm{Bi}$ & $2106 \mathrm{ABh}$ & $2167 \mathrm{ABj}$ & $2444 \mathrm{Abcde}$ & $1494 \mathrm{Ce}$ & 2040 \\
\hline Mean & 3067 & 3187 & 3419 & 2445 & 1945 & 2813 \\
\hline
\end{tabular}

Means followed by the same letter, lowercase in columns and uppercase in rows, do not differ by Tukey's test $(P<0.05)$.

$*$ Tukey's HSD at $5 \%$ probability between sowing dates $=411.30 \mathrm{~kg} \mathrm{ha}^{-1}$ and between genotypes $=522.40 \mathrm{~kg} \mathrm{ha}^{-1}$.

Among the sowing dates tested, the highest average yield occurred in soybeans planted on 12/07; however there was a significant decrease when the sowing date was postponed for at least 16 days $(12 / 23)$. There was substantial variability among genotypes for yield and grain quality in response to delayed sowing.

The cultivar Garantia showed a significant reduction in productivity only when sown on SD5, a delay of 67 days from SD1 (11/03), whereas the cultivars Conquista, UFVTN 102 and MSoy 8001 showed significant yield reductions from sowing on SD4 (12/23). Nine of the other genotypes had the highest crop yield when planted on SD3 (12/07); the Valiosa, Vencedora, and UFVS 2006 genotypes had the highest yield when sown on SD2 (11/20); and the Bioagro lineage had the highest yield when sown on SD4 (12/23). All genotypes had their lowest crop yield when sown on SD5 (01/09). According to Carvalho et al. (2021), a sowing delay promotes a significant reduction $(25 \%$ to $19 \%)$ in grain yield associated with a lower accumulation of dry matter in the grains with the shortening of the reproductive or vegetative phases. Cultivars with indeterminate growth show continuous plant growth and development even after flowering; consequently, an increase in the duration of the vegetative phase can provide plants with the possibility of fixing carbon and accumulating nitrogen, both of which are fundamental for increasing the productive potential of soybean (SINCLAIR et al., 2005).

Figure 6 shows the curves for the three genotypes with yields that are significantly explained by linear models, as well as the identity model that represents them. All three genotypes showed a reduction in yield due to a delay in sowing. In particular, the Elite genotype showed the greatest reduction in yield and the UFV 18 genotype had the smallest yield loss with delay in sowing. Sowing soybean on a date close to that of the ideal sowing time is most indicated, and relates to more adequate climatic conditions, especially temperature and water availability (CARVALHO et al., 2021).

Figure 7 shows the genotypes with datasets that generated quadratic yield models and the identity model that represents them. These genotypes showed an initial increase in crop yield followed by a sharp reduction with delay in sowing. The derivative of the model equation revealed that for these genotypes, a sowing delay of 25 days from the earliest sowing date resulted in higher grain yields. 


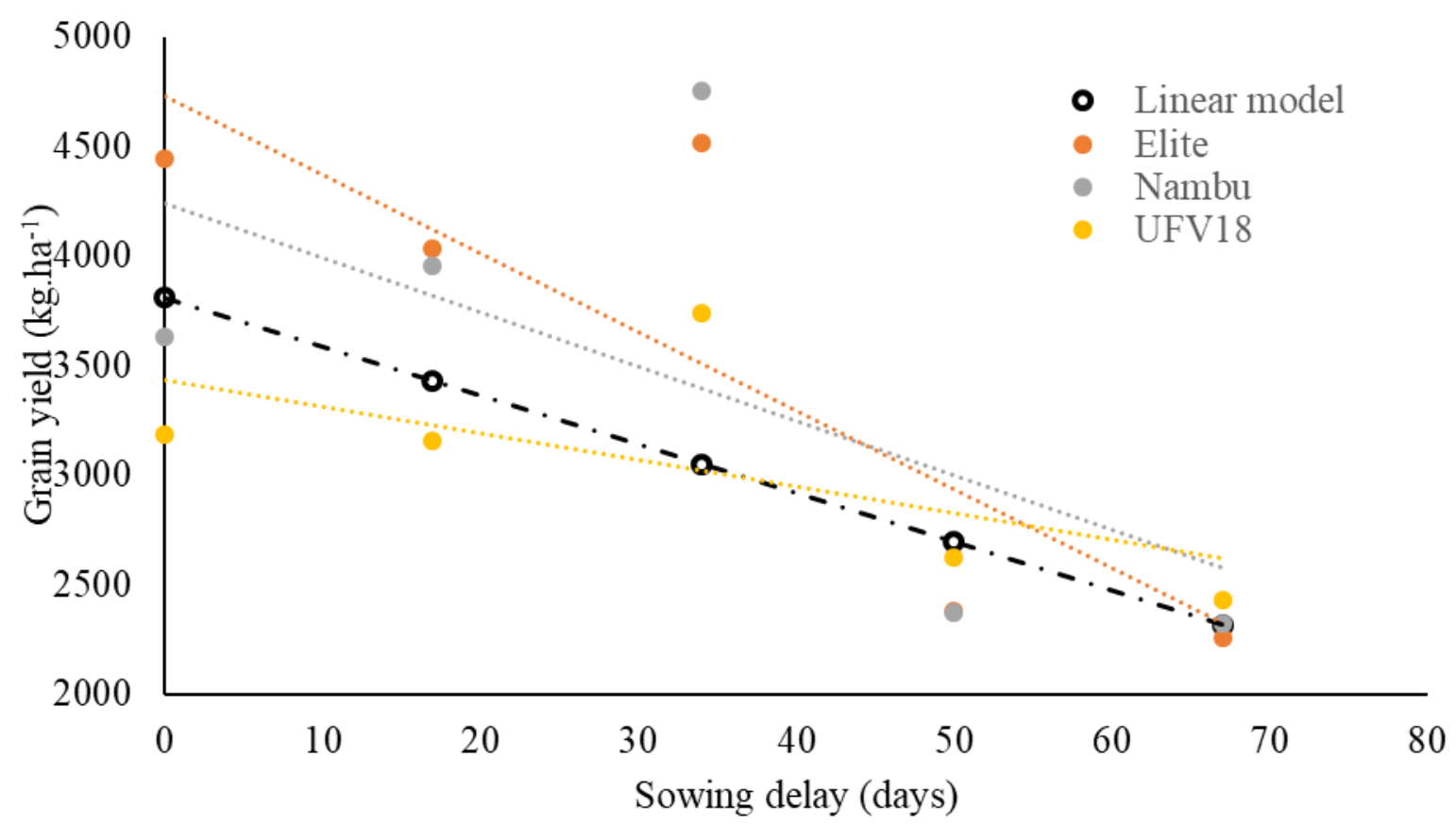

Figure 6. Relationship between the number of days of delay from the first sowing date (November 7th) and grain yield $\left(\mathrm{kg} \mathrm{ha}^{-1}\right)$ of soybean genotypes grown during the 2015/2016 agricultural year in Pindorama, north-central São Paulo State, Brazil. Linear identity model: $\mathrm{Y}=3,807.67-22.25 \mathrm{x}\left(\mathrm{R}^{2}=94.73\right)$.

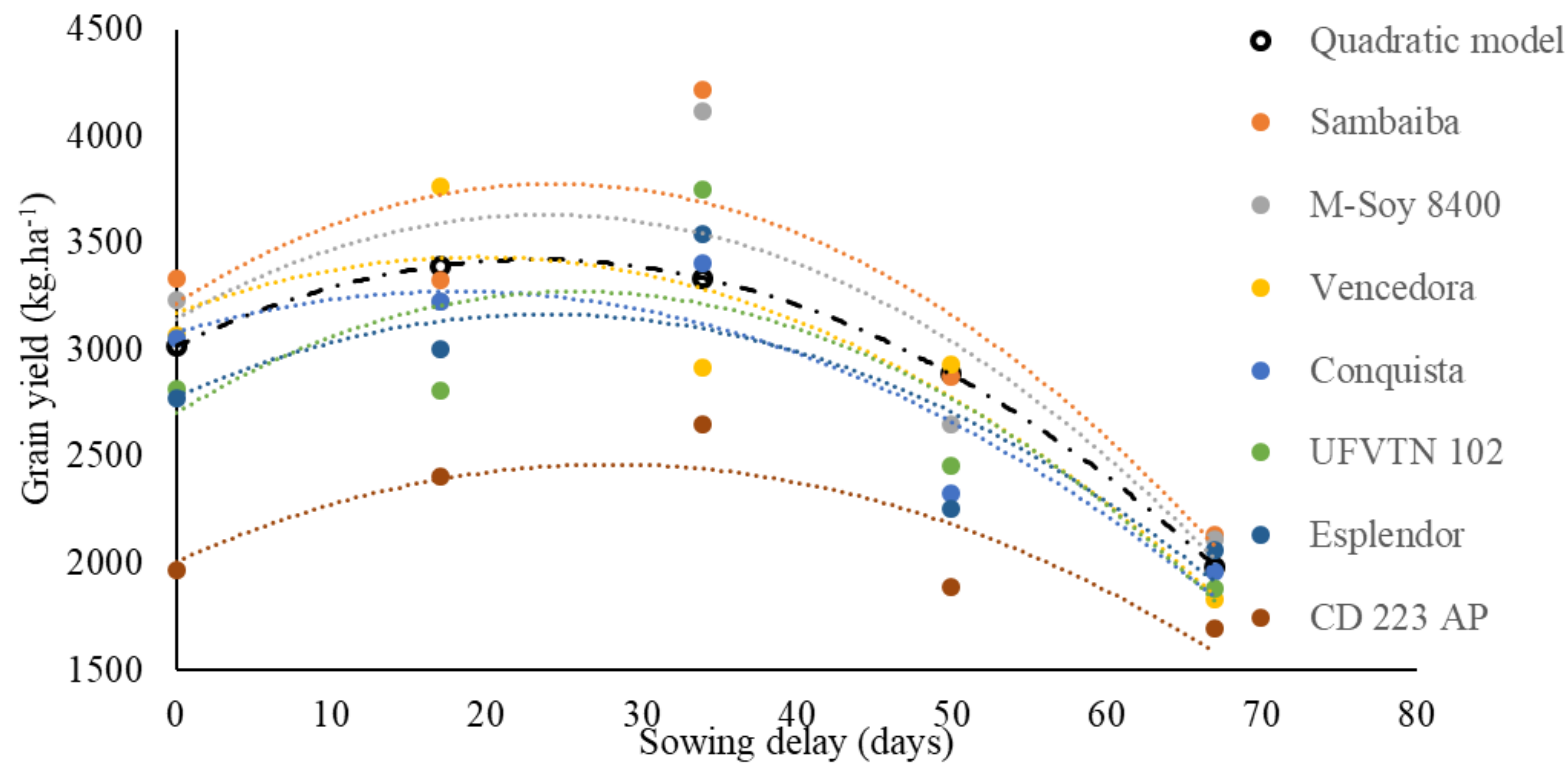

Figure 7. Relationship between the number of days of delay from the first sowing date (November 7th) and grain yield $\left(\mathrm{kg} \mathrm{ha}^{-1}\right)$ of soybean genotypes grown during the 2015/2016 agricultural year in Pindorama, north-central São Paulo State, Brazil. Quadratic identity model: $\mathrm{Y}=3016.12+34.92 \mathrm{X}-0.751 \mathrm{x}^{2}\left(\mathrm{R}^{2}=99.01\right)$.

Genotypes with datasets that generated cubic yield models are shown in Figure 8. In this case, the Garantia and Bioagro lineage genotypes were not significantly represented by the identity model because they presented differentiated data. There was a substantial response disparity between genotypes and sowing dates for the cubic model.
Table 6 contains the average soybean yield estimates and the Annicchiarico (1992) confidence index decomposition for favorable and unfavorable sowing dates according to the environmental indexes. Based on the confidence index or recommendation index for grain yield, the Elite, Nambu, Garantia, Sambaíba, Valiosa, M-Soy 8400, 
UFV 18 and M-Soy 8001 genotypes showed the best adaptation to the different dates of sowing with general confidence indexes higher than those estimated by the identity model $(118.4,115.4,114.2$, $110.5,105.5,106.8,106.2$, and 104.3, respectively). The confidence index decomposition for favorable (SD1, SD2, and SD3) and unfavorable (SD4 and SD5) sowing dates showed that these genotypes also performed better than estimated by the identity model for both scenarios, being considered stable for different sowing dates. The Vencedora genotype, even with a poorer overall performance than expected, had a higher yield than estimated for the later sowing times that were considered unfavorable. The genotypes best adapted to late sowing were UFV 18, Sambaíba, and Garantia.

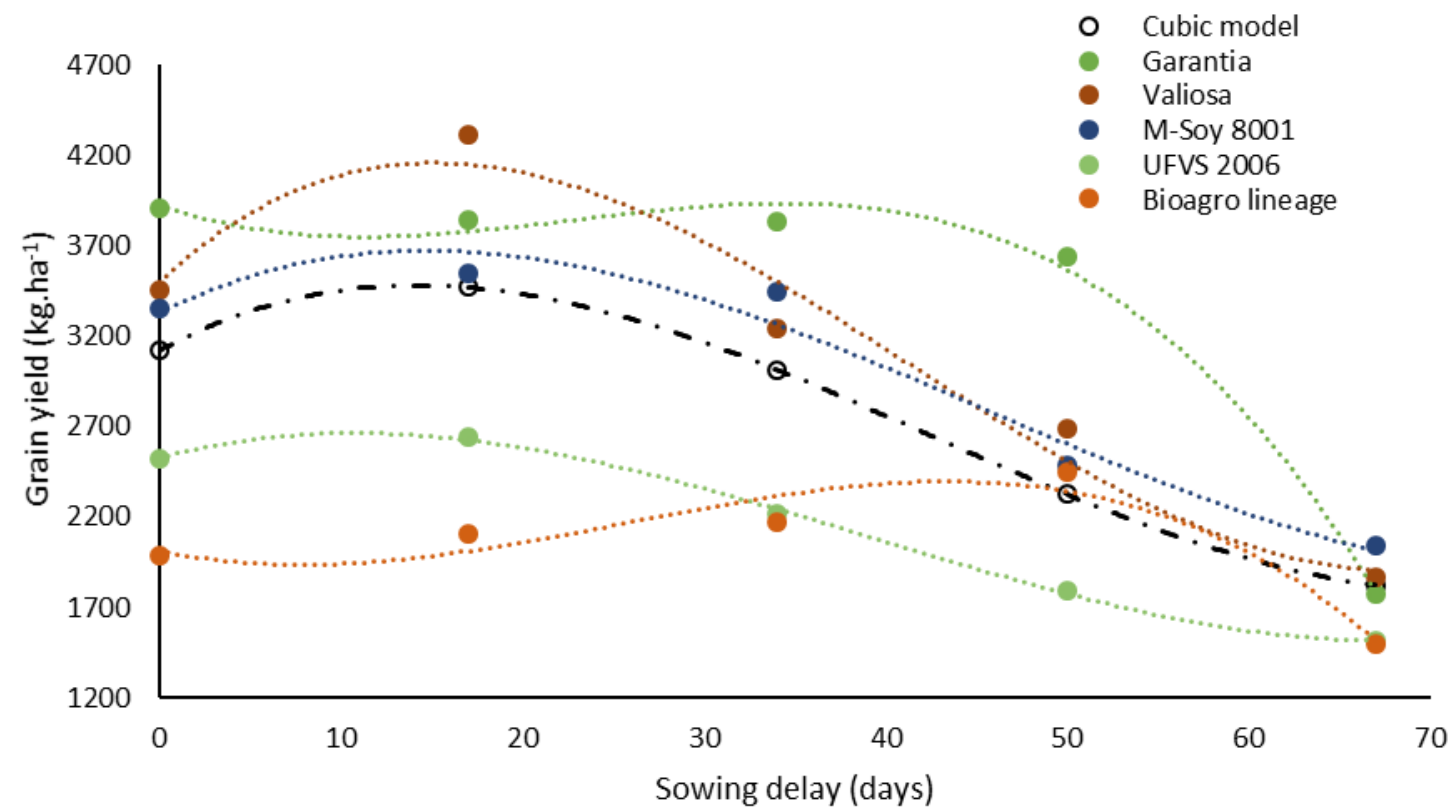

Figure 8. Relationship between the number of days of delay from the first sowing date (November 7th) and the grain yield $\left(\mathrm{kg} \mathrm{ha}^{-1}\right)$ of soybean genotypes grown during the 2015/2016 agricultural year in Pindorama, north-central São Paulo State, Brazil. Cubic identity model for grain yield of genotypes: $\mathrm{Y}=3120+54.62 \mathrm{x}-2.310 \mathrm{x}^{2}+0.018 \mathrm{x}^{3}\left(\mathrm{R}^{2}=97.21\right)$.

Table 6. Estimates of the means of grain yield $\left(\mathrm{kg} \mathrm{ha}^{-1}\right)^{*}$ and the confidence index $(W i)$ according to the method of Annicchiarico (1992). The confidence index was decomposed between favorable and unfavorable environments (sowing dates). A total of 17 soybean genotypes were grown during the 2015/2016 agricultural year in Pindorama, north-central São Paulo State, Brazil.

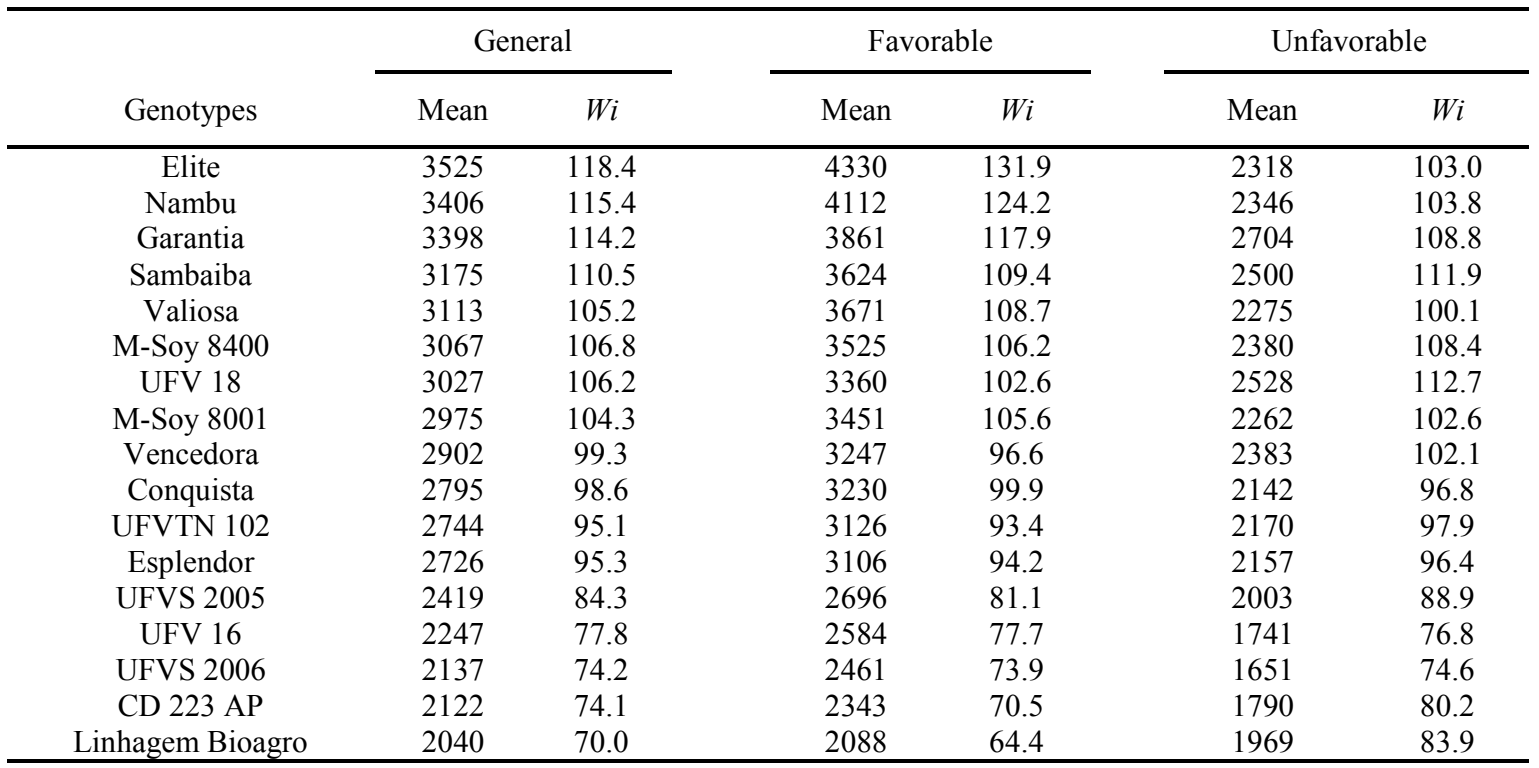

$*$ Alfa $=0.25 ; Z(1-$ alfa $)=0.2734$. 
The results obtained for grain oil and protein contents, and grain yield of soybean genotypes in the present study agree with those of Albrecht et al. (2008) who state that sowing anticipation provides climatic conditions that tend to increase grain oil content and productivity and reduce grain protein content.

\section{CONCLUSIONS}

The M-Soy 8001, UFV 18, and Garantia genotypes have high oil contents, with adaptation to all sowing dates, and stability with good performance when sown on both favorable and unfavorable sowing dates. The Bioagro lineage, CD 223 AP, and Garantia genotypes are better adapted and more stable when sown at all sowing dates, and have higher protein contents than the other genotypes, regardless of the sowing date. The Elite, Nambu, and Garantia genotypes are the best adapted and most stable for grain yield. These genotypes are highly productive in favorable environments, and respond better to sowing dates before mid-December. Garantia is the most suitable genotype for the cultivation conditions in Pindorama, in the north-central region of São Paulo State. This genotype performs well for all three evaluated characteristics, irrespective of sowing time.

\section{REFERENCES}

ALBRECHT, L. P. et al. Teores de óleo, proteínas e produtividade de soja em função da antecipação da semeadura na região oeste do Paraná. Bragantia, 67: 865-873, 2008.

ANNICCHIARICO, P. Cultivar adaptation and recommendation from alfafa trials in Northern Italy. Journal of Genetics and Breeding, 46: 269-278, 1992.

BÁRBARO-TORNELI, I. M. et al. Avaliação de cultivares de soja no estado de São Paulo em resposta à aplicação de inoculantes no sulco de semeadura. Nucleus, 1: 55-62, 2018.

BARBOSA, V. S. et al. Comportamento de cultivares de soja, em diferentes épocas de semeaduras, visando a produção de biocombustível. Revista Ciência Agronômica, 42: 742-749, 2011.

BORÉM, A.; MIRANDA, G. V. Interação genótipo $\mathrm{x}$ ambiente. Melhoramento de Plantas. 6. ed. Viçosa, MG: Editora UFV, 2013, p. 131-144.

BRUM, A. L. S.; ARRUDA, L. F.; REGITANOD'ARCE, M. A. B. Métodos de extração e qualidade da fração lipídica de matérias-primas de origem vegetal e animal. Química Nova, 32: 849-854, 2009.

BUENO, R. D. et al. Agronomia: colhendo as safras do conhecimento. Melhoramento genético visando qualidade do grão de soja, 1. ed. Alegre, ES: CAUFES, 2017, 225 p.

CALÇADO, J. P. et al. Épocas de semeadura e períodos de colheita de soja visando produção de óleo e proteínas. Nativa, 7: 376-382, 2019.

CARNEIRO, A. P. S. et al. Identidade de modelos não lineares para comparar curvas de crescimento de bovinos da raça Tabapuã. Pesquisa Agropecuária Brasileira, 49: 57-62, 2014.

CARVALHO, E. V. et al. A época de semeadura na produção de sementes de soja em condições de várzea tropical. Revista Sítio Novo, 5: 100-117, 2021

CONAB - COMPANHIA NACIONAL DE ABASTECIMENTO. Acompanhamento da Safra Brasileira de Grãos, safra 2020/21, Boletim da safra de grãos, 8: 1-97, 2021.

CRUZ, C. D. GENES: a software package for analysis in experimental statistics and quantitative genetics. Acta Scientiarum, 35: 271-276, 2013.

CRUZ, C. D.; CARNEIRO, P. C. S.; REGAZZI. A J. Modelos Biométricos Aplicados ao Melhoramento Genético. 3. ed. Viçosa, MG: UFV, 2014. $668 \mathrm{p}$

DELARMELINO-FERRARESI, L. M.; VILLELA, F. A.; AUMONDE, T. Z. Desempenho fisiológico e composição química de sementes de soja. Revista Brasileira de Ciências Agrárias, 9: 14-18, 2014.

FARIA, L. A. et al. Teor de óleo e proteína no grão de cultivares de soja em diferentes épocas de semeadura. Revista Brasileira de Ciências Agrárias, 13: e5518, 2018.

FIETZ, C. R.; RANGEL, M. A. S. Época de semeadura da soja para a região de Dourados-MS, com base na deficiência hídrica e no fotoperíodo. Engenharia Agrícola, 28: 666-672, 2008.

FINOTO, E. L. et al. Antecipação e retardamento de colheita nos teores de óleo e proteína das sementes de soja, cultivar Valiosa RR. Scientia Agropecuaria, 8: 99-107, 2017.

HACKENHAAR, N. M. et al. Potássio e época de semeadura em cultivares de soja para teor de óleo e proteína. Acta Iguazu, 8: 1-11, 2019. 
HERRERA, G .C. et al. Adaptabilidade e estabilidade de linhagens de soja na região sul do Brasil por meio de modelagem mista. Journal of Agronomic Sciences, 9: 185-202, 2020.

LOPES, J. A. M et al. Teor de proteína e óleo em grãos de soja, em diferentes épocas de plantio para fins industriais. Tecnologia \& Ciência Agropecuária, 10: 49-53, 2016.

NAOE, A. M. L. et al. Effect of water deficit and sowing date on oil and protein contents in soybean co-inoculated with Azospirillum brasiliense. Pesquisa Agropecuária Tropical, 51: e66584, 2021.

PRABHAKAR, K. et al. Seed yield and quality of soybean [Glycine Max (L.) Merill] as influenced by cultivar and sowing date in vertisols of Andhra Pradesh during Kharif season. Legume ResearchAn International Journal, 41: 281-286, 2018.

SILVA, R. R. et al. Adaptabilidade e estabilidade de cultivares de trigo em diferentes épocas de semeadura, no Paraná. Pesquisa Agropecuária Brasileira, 46: .1439-1447, 2011.

SINCLAIR, T. R. et al. Comparison of vegetative development in soybean cultivars for low latitude environments. Field Crops Research, 92: 53-59, 2005.

VAZQUEZ, G. H. et al. Produtividade de grãos de cultivares de soja em três épocas de semeadura no noroeste paulista. In: CONGRESSO TÉCNICO CIENTÍFICO DA ENGENHARIA E DA AGRONOMIA. 6., 2019, Palmas. Anais... 2019, Palmas: Centro de Convenções Arnaud Rodrigues, 2019. p. 1-5. 